\title{
ISOLATION AND CHARACTERIZATION OF A POTENTIALLY PROBIOTIC LACTOBACILLUS DELBRUEKII SSP. LACTIS FROM QARISH CHEESE
}

\author{
Azza Abdel aziz Abou zeid, Yehia A. El - Zawahry, Essam Kotb Abd-Elmoneam and \\ Osamah Zuhair Noori
}

Zagazig University, Faculty of Science, Botany Department

Corresponding author: usamazuhair@hotmail.com

\begin{abstract}
Probiotics are non- pathogen living microorganisms which express beneficial effects on host, when are administered in adequate amounts. The present study was undertaken to isolate and characterize certain lactic acid bacteria (LAB) isolate which could be used as a probiotic

LAB was isolated by culturing the samples on MRS agar. The isolates were screened for their probiotic potential using in-vitro tests, including tolerance to acid and bile, survival in simulated gastrointestinal tract conditions, and hemolytic activity as well as antibiotic susceptibility. In addition, antibacterial activity of the isolated strains against E. coli $O 157$ and Salmonella enterica was determined.

Lactobacillus delbruekii ssp. lactis showed the highest tolerance to low $\mathrm{pH}$, bile and simulated gastrointestinal tract conditions. This strain exhibited resistance to Nalidixic acid, Cloxacillin, Aztreonam and Colistin as well as effective antibacterial activity against two Gram negative pathogens, lacking hemolytic activity. Finally, the strain was identified as Lactobacillus delbruekii ssp. lactis using biochemical characterization and $16 S$ rRNA sequencing assay.

Discussion and conclusion: In the present work, a potentially probiotic was Lactobacillus delbruekii ssp. lactis isolated from dairy product (Qarish Cheese). The bacterium displayed good probiotic properties.
\end{abstract}

Key words: Lactic acid bacteria, Lactobacillus delbruekii ssp. lactis, Probiotics, dairy product (Qarish Cheese). 


\section{Introduction}

Probiotics are non-pathogenic microorganisms that when ingested in adequate amounts, exert a positive influence on their host's health (Schlundt, 2012). A variety of microorganisms typically food grade has been evaluated for their probiotic potential and are applied as adjunct cultures in various types of food products or in therapeutic preparations (Rodgers, 2008).

Probiotics are defined as live microorganisms that are believed to provide health benefits when consumed (Hill et al., 2014). The term probiotic is currently used to name ingested microorganisms associated with benefits for humans and animals (Magdalena, et al., 2006).

Probiotics are considered to be generally safe, but they may cause bacteria-host interactions and unwanted side effects in rare cases ( Singhi and Kumar, 2016).

In addition, probiotics should be non-pathogenic, stable in acid and bile, able to adhere to and colonize human gut mucosa. They should be scientifically demonstrated to have beneficial physiological effects and safety so that they can be used to improve microbial balance and to confer health benefit, especially of LAB strains (Singhi and Baranwal, 2008). Cheese have been considered as good sources of LAB and ideal vehicles to deliver probiotic bacteria to human gastroinstestinal tract (Karimi et al., 2012).

The aim of the present study was to isolate LAB from Qarish Cheese and to investigate their probiotic potential. In addition, inhibitory activity of the isolates against E. coli $O 157$ and Salmonella enterica has also been studied.

\section{Materials and Methods}

Sample collection and isolation of LAB: Samples were collected aseptically from ten different markets in the Sharqia Governorate, Egypt (Qarish Cheese). Stored at $4{ }^{\circ} \mathrm{C}$ and transferred immediately to the laboratory. The homogenized suspension was serially diluted in $0.1 \%$ peptone water and $1 \mathrm{~mL}$ of appropriate dilution $\left(10^{-1}, 10^{-2}\right.$ and $\left.10^{-3}\right)$ was plated on to MRS agar (Thongaram, 2016). $\mathrm{pH} 6.2$ and $\mathrm{pH} 5.5$, The plates were incubated at $37{ }^{\circ} \mathrm{C}$ for $48 \mathrm{~h}$. the Gram positive, catalase negative, non-motile bacterial isolates were purified using streak culture technique and stored at $4^{\circ} \mathrm{C}$.

Acid and bile tolerance: Tolerance to acid was determined according to the method described earlier (Yu et al., 2013), as the following: isolated strains were 
grown in MRS broth at $37^{\circ} \mathrm{C}$ for $48 \mathrm{~h}$, and sub-cultured in fresh MRS broth adjusted to $\mathrm{pH} 2.0$ with hydrochloric acid. The initial bacterial concentration was adjusted to $10^{7} \mathrm{CFU} / \mathrm{mL}$ and their survival was determined after 60 and $120 \mathrm{~min}$ at $\mathrm{pH}$ 2.0. Bile tolerance test was conducted using the method described by $\mathbf{Y u}$ and Tsen, (1993).

The Isolated bacteria were grown in MRS broth with and without 3\% (w/v) bile. The cultures were incubated at $37^{\circ} \mathrm{C}$ and the growth was monitored by measuring their optical densities (OD) at $620 \mathrm{~nm}$. The bile tolerance was estimated by comparing cell growth of organisms.

Resistance to lysozyme: The tolerance for the isolated bacteria against lysozyme was determined by the method of Zago et al, (2011). The culture was grown in $10 \mathrm{~mL}$ MRS medium at $25^{\circ} \mathrm{C}$ and $180 \mathrm{rpm}$ for $10-12 \mathrm{~h}$. The cells were centrifuged at 10,000 rpm for $15 \mathrm{~min}$. The cell pellet was washed with $5 \mathrm{~mL}$ of phosphate buffer saline ( $\mathrm{pH} 7.0$ ) two times and resuspended in $2 \mathrm{~mL}$ of Ringer solution, $0.5 \mathrm{~mL}$ suspension of the isolated bacteria was inoculated in $5 \mathrm{~mL}$ sterile electrolyte solution (SES; $0.22 \mathrm{~g} / 1 \mathrm{CaCl} 2,6.2 \mathrm{~g} / \mathrm{l} \mathrm{NaCl}, 2.2 \mathrm{~g} / 1 \mathrm{KCl}, 1.2 \mathrm{~g} / \mathrm{l}$ $\mathrm{NaHCO} 3$ ) containing $100 \mathrm{mg} / \mathrm{l}$ of lysozyme (Titan Biotech L.TD. Rajasthan, India) and incubated at $37^{\circ} \mathrm{C}$ for $2 \mathrm{~h}$. The bacterial suspension in sterile electrolyte solution without lysozyme was taken as a control. The aliquot (100 $\mu 1)$ from sample was spread on to MRS agar plates and incubated at $25^{\circ} \mathrm{C}$ for $48 \mathrm{~h}$. The microbial colonies grown on plates were counted and their survival was calculated as percent of $\mathrm{CFU} / \mathrm{mL}$ (colony forming unit per $\mathrm{mL}$ ) obtained from lysozyme treatment with respect to the control (without lysozyme treatment).

Tolerance against gastric juice: The tolerance of washed cell suspensions for the isolated bacteria to simulate gastric (pepsin, $3 \mathrm{~g} / 1$ in sterile saline $(0.5 \%)$ and adjusting the simulated gastric juices $\mathrm{pH}$ to 2.0 with concentrated $\mathrm{HCl}$ ) was determined as described by Charteris et al, (1998). To $0.2 \mathrm{~mL}$ of washed cell suspension in a $2.0 \mathrm{~mL}$ capacity screw-cap microfuge were mixed to $1.0 \mathrm{~mL}$ of simulated gastric $(\mathrm{pH} 2.0)$ and $0.3 \mathrm{~mL} \mathrm{NaCl}(0.5 \% \mathrm{w} / \mathrm{v})$. The materials were vortexed at setting 5 for 10 second and incubated at $37{ }^{\circ} \mathrm{C}$. When assaying gastric transit tolerance, aliquots of $0.1 \mathrm{~mL}$ were removed after 0 and $180 \mathrm{~min}$ for determination of total viable count.

Tolerance against simulated pancreatic juices: The tolerance of washed cell suspensions for the isolated bacteria to small intestinal transit was determined as described by Charteris et al, (1998). To $0.2 \mathrm{~mL}$ of washed cell suspension in a $2.0 \mathrm{~mL}$ capacity screw-cap microfuge tube were admixed $1.0 \mathrm{~mL}$ of pancreatic juice (panceratin $1 \mathrm{~g} / \mathrm{l}$ ) in sterile saline $(0.5 \%)$ and adjusting the $\mathrm{pH}$ to 8.0 with 
concentrated $0.1 \mathrm{M} \mathrm{NaOH}$. The materials were vortexed at setting 5 for 10 second and incubated at $37{ }^{\circ} \mathrm{C}$. When assaying transit tolerance, aliquots of 0.1 $\mathrm{mL}$ were removed after 0 and $240 \mathrm{~min}$ for determination of total viable count when assaying for small intestinal transit tolerance.

Antibiotic resistance: Antibiotic resistance was examined by the disc diffusion method described by Thirabunyanon and Boonprasom, (2009). The isolates to be tested were grown overnight in fresh MRS broth of $\mathrm{pH} 6.4$ at $37{ }^{\circ} \mathrm{C}$. About $100 \mu \mathrm{l}$ of the suspension was spread onto the surface of the MRS agar plates. The antibiotic disks were inserted aseptically onto the agar surface. The plates were then incubated under anaerobic conditions for $24 \mathrm{~h}$ at $37^{\circ} \mathrm{C}$. The antibiotic resistance of the isolates was determined by calculating the diameter of the zones of inhibition around the antibiotic disks. The susceptibility was expressed in terms of resistance (R), intermediate susceptibility (I), and susceptibility (S) based on data from the National Committee for Clinical Laboratory Standards NCCLS, (2002).

In order to evaluate hemolytic activity of the isolates, fresh bacterial cultures were plated on Columbia agar base plates containing 5\% v/v human blood. The plates were examined for signs of $\beta$ - hemolysis (clear zones around colonies), $\alpha-$ hemolysis (green-hued zones around colonies) or $\gamma$ - hemolysis (no zones around colonies) following $48 \mathrm{~h}$ incubation at $37^{\circ} \mathrm{C}$. (Mohamed et al., 2015).

Antimicrobial activity against Gram negative pathogens: Antimicrobial activity was carried out according to agar well diffusion assay as described previously (Rammelsberg and Radler, 1990). Escherichia coli O157:H7, Salmonella enterica, (strain were kindly provided from bacterially laboratory, faculty of medicine, zagazig university) were cultured in brain heart infusion (BHI) broth for $24 \mathrm{~h}$., then microbial density was adjusted to $10^{7} \mathrm{CFU} / \mathrm{mL}$ and cultured on nutrient agar. Lactobacillus delbruekii ssp. lactis was grown in MRS broth under anaerobic condition at $37{ }^{\circ} \mathrm{C}$ for $20 \mathrm{~h}$. Cell free culture supernatants (CFCS) were obtained by centrifuging the MRS broth at $10000 \mathrm{rpm}$. for $15 \mathrm{~min}$. $100 \mu 1$ of the CFCS was placed into the wells of the nutrition agar, there the plates were incubated at $37{ }^{\circ} \mathrm{C}$ for $15 \mathrm{~h}$., The diameter of the clear zones around each well was measured. Strains with clear zones less than $11 \mathrm{~mm}, 11-16 \mathrm{~mm}$, 17-22 $\mathrm{mm}$ and more than $23 \mathrm{~mm}$, were grouped as negative $(-)$, mild $(+)$, strong (++ ), and very strong (+++ ) inhibitor, respectively. Sterile MRS broth was used as negative control. Two major mechanisms of antimicrobial activity are production of organic acids, which reduce the $\mathrm{pH}$ and the production of hydrogen peroxide and bacteriocins replicates. 
Biochemical and molecular identification of the isolated strain: Based on the results of the assays described above, one strain was identified using physiological and biochemical tests according to Bergey's Manual of Systematic Bacteriology vol.2 (Holt and Krieg, 1984). In order to confirm the result from biochemical characterization, $16 S$ rRNA sequencing was performed. Briefly, total DNA from isolated strain was extracted using (GeneJet genomic DNA purification Kit Thermo K0721 USA) according to the manufacturer's manual. Then, $16 S$ rRNA gene was amplified using the $\mathrm{F}$ (5' AGA GTT TGA TCC TGG CTC AG 3') and R (5' GGT TAC CTT GTT ACG ACT T 3') primers (Eden $\boldsymbol{e t}$ al., 1991)). The thermal cycler was programmed as follows: $10 \mathrm{~min}$ at $95^{\circ} \mathrm{C} ; 37$ cycles of $1 \mathrm{~min}$ at $95^{\circ} \mathrm{C}, 1 \mathrm{~min}$ at $65^{\circ} \mathrm{C}, 1 \mathrm{~min}$ at $72^{\circ} \mathrm{C}$ and $10 \mathrm{~min}$ at $72^{\circ} \mathrm{C}$.

\section{Results}

Isolation and identification of potent probiotic strain: the bacterial strain (Lactobacillus delbruekii ssp. lactis) isolated from Qarish cheese was Gram positive, Catalase negative, non-motile rod was regarded as LAB and further characterized as potent probiotic strains. Identification of this strain using physiological, biochemical and molecular assays was performed.

Acid and bile tolerance: Acid tolerance assay showed that Lactobacillus delbruekii ssp. lactis tolerated $\mathrm{pH} 2$ after 120 min incubation with survival percentage of $80 \%$ compared to the control. The bacterial isolate treated with $0.3 \%$ bile salt, showed high resistant with survival rates $100 \%$ compared to bacteria treated without bile salt. the increment of O.D. for MRS broth with bile was equal to the increment of O.D. for MRS broth without bile.

Resistance to condition simulating GI tract: Lactobacillus delbrueckii ssp. lactis showed resistance to $100 \mu \mathrm{g} / \mathrm{mL}$ of lysozyme with $80 \%\left(2.03 \times 10^{6}\right.$ $\mathrm{CFU} / \mathrm{mL}$ ) survival after $2 \mathrm{~h}$. as compared to control having $2.51 \times 10^{6} \mathrm{CFU} / \mathrm{mL}$. While, the percent survival of Lactobacillus delbrueckii ssp. lactis showed resistance to $100 \mu \mathrm{g} / \mathrm{mL}$ of simulated gastric with $93 \%\left(1.61 \times 10^{6} \mathrm{CFU} / \mathrm{mL}\right)$ survival after $3 \mathrm{~h}$. as compared to total viable count in control $\left(1.72 \times 10^{6}\right.$ $\mathrm{CFU} / \mathrm{mL}$ ) after $0 \mathrm{~h}$. Our results revealed that the isolate Lactobacillus delbrueckii ssp. Lactis was highly susceptible to Panceratin solution ( $\mathrm{pH}$ 8.0) while, the solution had less effect on survival rate of isolate Lactobacillus delbrueckii ssp. lactis. Isolate showed survival percentage of $31 \%\left(1.00 \times 10^{6}\right.$ $\mathrm{CFU} / \mathrm{mL})$ survival after $4 \mathrm{~h}$ as compared to total viable count in control $(3.10 \mathrm{x}$ $10^{6} \mathrm{CFU} / \mathrm{mL}$ ) after $0 \mathrm{~h}$, (Diagram, 1). 


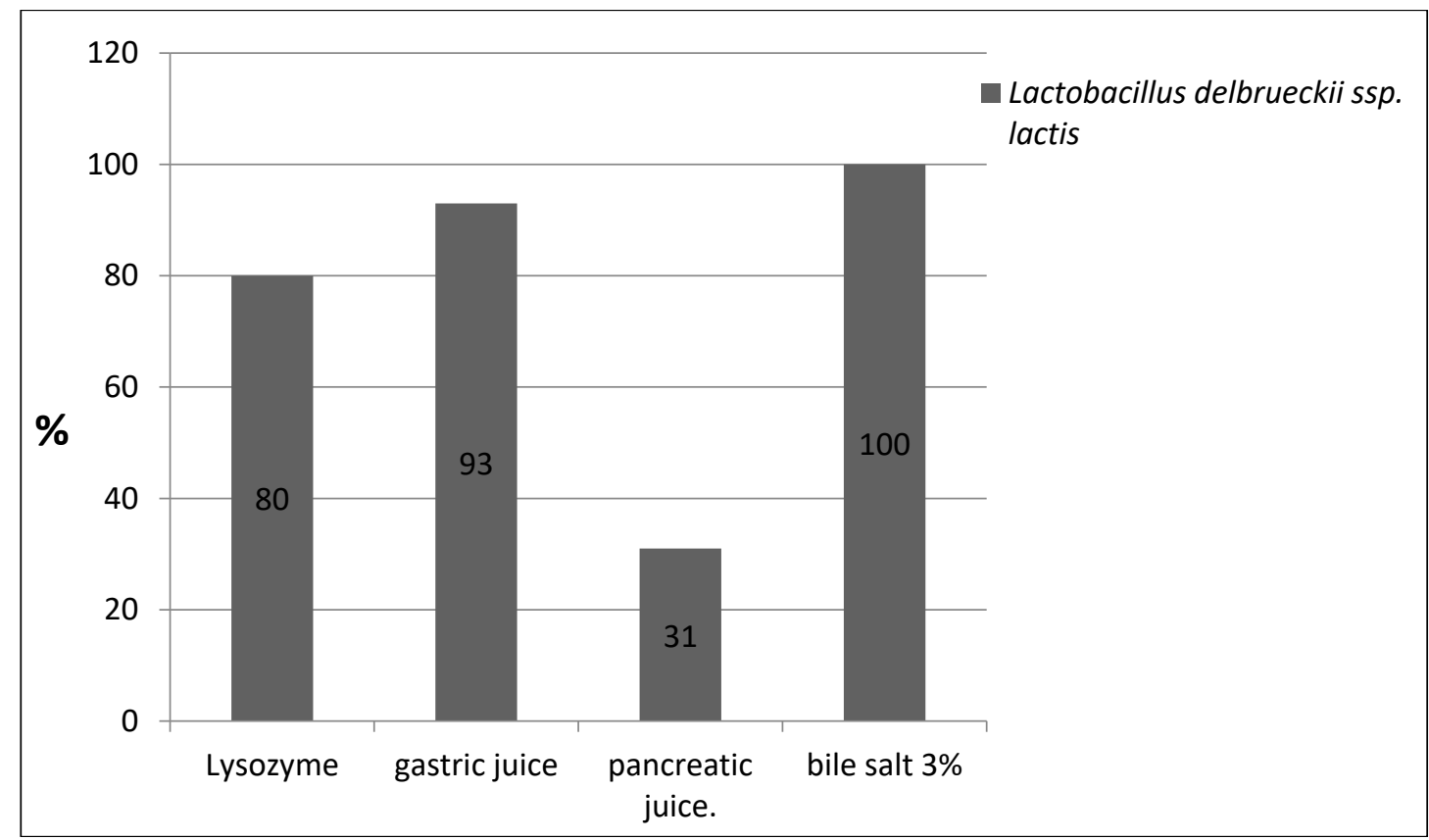

Diagram (1). Effect of lysozyme, gastric juice, pancreatic juice, bile salt $3 \%$ on survival rate of Lactobacillus delbrueckii ssp. lactis

Antibiotic susceptibility and hemolytic activity: The Lactobacillus delbrueckii ssp. lactis showed resistance to majority of antibiotics used in this study, it's showed 100\% resistant to Nalidixic acid, Cloxacillin, Aztreonam and Colistin. Table (1). In addition, none of isolates exhibited hemolytic activity.

Antimicrobial activity against Gram negative pathogens: Antibacterial activity is an important feature of the probiotic strain. The isolate was checked for their antibacterial activity against two gastrointestinal pathogens, E. coli O157 and S. enterica. The results revealed that Lactobacillus delbrueckii ssp. lactis. Inhibited both tested strain (Escherichia coli O157:H7, Salmonella enterica) with zone diameter more than $15 \mathrm{~mm}$. 
Table (1): Showed the Lactobacillus delbrueckii ssp. lactis resistant to antibiotic. $\mathrm{R}=$ Resistant, $\mathrm{S}=$ Sensitive, $\mathrm{I}=$ Intermediate Resistant.

\begin{tabular}{lc}
\hline Types of antibiotic & Lactobacillus delbrueckii ssp. lactis \\
\hline Cefoperazone & $\mathrm{I}$ \\
Nalidixic acid & $\mathrm{R}$ \\
Penicillin G & $\mathrm{S}$ \\
Levofloxacin & $\mathrm{I}$ \\
Cloxacillin & $\mathrm{R}$ \\
Cefadroxil & $\mathrm{I}$ \\
Cefoperazone / sulbactam & $\mathrm{S}$ \\
Aztreonam & $\mathrm{R}$ \\
Gatifloxacin & $\mathrm{I}$ \\
Ampicillin & $\mathrm{I}$ \\
Rifampin & $\mathrm{S}$ \\
Colistin & $\mathrm{R}$ \\
Cefaclor & $\mathrm{S}$ \\
Flucloxacillin & $\mathrm{R}$ \\
Cefamandole & $\mathrm{S}$ \\
Erythromycin & $\mathrm{S}$ \\
Chloramphenicol & $\mathrm{S}$ \\
Clindamycin & $\mathrm{S}$ \\
Doxycycline & $\mathrm{S}$ \\
Carbenicillin & $\mathrm{I}$ \\
Streptomycin & $\mathrm{R}$ \\
Oxacillin & $\mathrm{I}$ \\
Amoxicillin / clavulanic acid & $\mathrm{I}$ \\
Imipenem & $\mathrm{I}$ \\
Amikacin & $\mathrm{S}$ \\
Netilmicin & $\mathrm{R}$ \\
Ceftazidime & $\mathrm{I}$ \\
Tobramycin & \\
Gentamicin & Cefoxitin
\end{tabular}

\section{Discussion and conclusion}

In the current work, Qarish cheese was examined in order to isolate LAB and some established in-vitro tests were applied to evaluate the probiotic potential of the isolates. The isolate was found to display potentially probiotic characteristics. 
Identification of this strain using biochemical and molecular assays showed the presence of the Lactobacillus delbrueckii ssp. lactis as a potent probiotic strain in Qarish cheese. For a probiotic strain, survival under gastrointestinal environment condition is important criteria to be fulfilled which depends on tolerance to low $\mathrm{pH}$ and high bile concentration as well as resistance to gastrointestinal enzymes. Tolerance to extremely acidic condition is an important feature of a probiotic strain (Guo et al., 2009). Lactobacillus delbrueckii ssp. lactis isolated from Qarish cheese showed good tolerance to low $\mathrm{pH}$ showing its ability to survive under acidic environment of stomach. This result agreement with Ashraf and Smith, (2016). The physiological concentration of bile in the small intestinal

appear able to grow in $0.3 \%$ bile salt during the third to the 4 hours after incubation and the OD620 were observed through this time to monitored viable colonies growth. Similar finding was reported by Yavuzdurmaz, (2007) who studied the tolerance of different strains of Lactic acid species and found that all of the probiotic bacteria isolates are resistant to $0.3 \%$ bile salt during 4 hours as they survive. The CFU values and OD620 were observed.

The present study showed that overall the 7 probiotic bacteria isolates (Lactobacillus delbrueckii sp. lactis resistance to lysozyme $100 \mu \mathrm{g} / \mathrm{mL}$ after $48 \mathrm{~h}$. of incubation. This result similar with Riaz, et al, (2015) they found the LAB strains from dairy origin were to be resistant at all concentration of lysozymes. the lysozyme was used in different concentrations i.e. $200 \mu \mathrm{g} / \mathrm{mL}$, $300 \mu \mathrm{g} / \mathrm{mL}$. The indigenous LAB strains were found to have growth in up to $300 \mu \mathrm{g} / \mathrm{mL}$ concentration of lysozyme. Also, the current result showed that the Lactobacillus delbrueckii ssp. lactis, isolate tolerance to simulated gastric juice $(\mathrm{pH} 2)$ after 3 hours incubation. This result agreed with Ashraf and Smith, (2016) where they found that all tested strains exhibited survival during simulated gastric transit at $\mathrm{pH} 2$ and $\mathrm{pH} 3$ for 3 hours. An essential element in their selection is their ability to reach, survive and persist in the environment in which they are proposed to act.

where viability of these cultures is affected mainly by gastric acid present in the stomach. the strain exhibited survival during simulated gastric transit at $\mathrm{pH} 3$ for 3 h.; however, viability was affected at $\mathrm{pH} 2$. demonstrated survival rate more than $50 \%$ and retained viability during 3 hours exposure to pepsin $\mathrm{pH} 2$ and are considered intrinsically tolerant to gastric transit.

The tolerance against simulated pancreatic juices (small intestinal transit), probiotic bacteria isolate in this study appear tolerance against pancreatic juices [ $1.0 \mathrm{~mL}$ of pancreatic ( $\mathrm{pH} 8.0)$ juice and $0.3 \mathrm{~mL} \mathrm{NaCl}(0.5 \% \mathrm{w} / \mathrm{v})]$ after 4 hours 
incubation. This result is similar with Zamani $\boldsymbol{e t}$ al, (2016) who recorded that not dramatically decrease survivors of probiotic bacteria strains even after 4 hours incubation.

Frequent antibiotic administration causes gut microbiota imbalance and an increased susceptibility to infection was caused by opportunistic microorganisms (Le Blanc et al., 2010) Probiotic strains which are resistant to antibiotics can proliferate in gut and maintain microbial balance and reduce opportunistic microorganisms (Guo et al., 2009). The isolated of probiotic bacteria showed resistance to multiple antibiotics. It's showed $100 \%$ resistant to Nalidixic acid, Cloxacillin, Aztreonam and Colistin, this result agreement with Ashraf and Shah, (2011) and Radulović et al, (2012), the result showed that no blood hemolysis was observed, indicatory that they were non- pathogenic, this agreement with Maragkoudakis et al, (2006).

During the present study Lactobacillus delbrueckii ssp. lactis which showed good tolerance when investigated for antimicrobial activity against the enteropathogenic bacteria (Escherichia coli O157:H7, Salmonella enterica), appeared clear inhibition zone around the each well. The diameter of the inhibition area was proportional to the antimicrobial activity of probiotic bacteria. The inhibition of Lactobacillus against these pathogenic bacteria had been reported in previous studies (Ammor et al., 2006; Tulumoglu et al., 2013; Asurmendi et al., 2015).

The use of bacteriocin- producing LAB could play a role in controlling colonization by pathogenic and spoilage bacteria in food processing facilities, they may lead to inhibition or killing the pathogenic bacteria.

Lactobacillus delbrueckii ssp. lactis as a potential probiotic strain was isolated from Qarish Cheese, its probiotic features were characterized. This isolate showed tolerance to high bile concentration, low $\mathrm{pH}$ and survived under condition simulating human gastrointestinal tract. Thus, it could be predicted that the isolate would be able to pass stomach and reach intestine in adequate amounts. In addition, this strain displayed a good antibacterial activity against two Gram negative food-borne pathogens. Thus, L. delbrueckii ssp. lactis could be considered as a good probiotic candidate. However, further investigations including in-vivo experiments as well as molecular analysis would be helpful to elucidate its potential health benefits. 


\section{References}

Ammor, S.; Tauveron, G.; Dufour, E. and Chevallier, I. (2006). Antibacterial activity of lactic acid bacteria against spoilage and pathogenic bacteria isolated from the same meat small-scale facility: 1 - Screening and characterization of the antibacterial compounds. Food Control 17, 454-461.

Ashraf, R. and Shah, N. P., (2011). Review Article Antibiotic resistance of probiotic organisms and safety of probiotic dairy products. International Food Research Journal 18: 837- 853.

Ashraf, R. and Smith, S.C. (2016). Commercial lactic acid bacteria and probiotic strains- tolerance to bile, pepsin and antibiotics. International Food Research Journal 23(2): 777-789.

Asurmendi, P.; García, MJ.; Pascual, L., Barberis, L. (2015). Biocontrol of Listeria monocytogenes by lactic acid bacteria isolated from brewer's grains used as feedstuff in Argentina. J Stored Prod Res. 61:27-31.

Charteris, WP.; Kelly, PM.; Morelli, L. and Collins, JK. (1998). Development and application of an in vitro methodology to determine the transit tolerance of potentially probiotic Lactobacillus and Bifidobacterium species in the upper human gastrointestinal tract. J Appl Microbiol. 84:759-768.

Eden, PA.; Schmidt, TM.; Blakemore, RP. and Pace, NR .(1991). Phylogenetic analysis of Aquaspirillum magnetotacticum using polymerase chain reaction-amplified $16 \mathrm{~S}$ rRNA-specific DNA. nt J Syst Bacteriol. 41(2):324-5.

Guo, Z.; Wang, J.; Yan L.; Chen W.; Liu X. and Zhang H. (2009). In vitro comparison of probiotic properties of Lactobacillus casei Zhang, a potential new probiotic, with selected probiotic strains. LWT- Food Science and Technology 2009; 42 (10): 1640- 6.

Hill, C.; Guarner, F.; Reid, G.; Gibson, GR.; Merenstein, DJ.; Pot, B.; Morelli, L.; Canani, RB.; Flint, HJ.; Salminen, S.; Calder, PC. and Sanders, ME (2014). "Expert consensus document. The International Scientific Association for Probiotics and Prebiotics consensus statement on the scope and appropriate use of the term probiotic.". Nature Reviews. Gastroenterology \& Hepatology. 11 (8): 506-14.

Holt, J.G. and Krieg, N.R. (1984). In Bergey's Manual of Systemic Bacteriology Genus Azotobacter sp., vol. (II). Williams, Wilkins, Baltimore, USA, pp. 225-229. 
Karimi R.; Mortazavian AM. and Amiri-Rigi A. (2012) Selective enumeration of probiotic microorganisms in cheese. Food Microbiology. 29 (1): $1-9$.

Le Blanc AM.; Castillo NA. and Perdigon G. (2010). Anti-infective mechanisms induced by a probiotic Lactobacillus strain against Salmonella enterica serovar Typhimurium infection. International Journal of Food Microbiology. 138 (3): 223-31.

Magdalena, A.; Catherine, S.; Lorenzo, M.; Gregor, R.; Maya, P., et al., (2006). "Probiotics in food: health and nutritional properties and guidelines for evaluation," Combined Report of a Joint FAO/WHO Expert Consultation on Evaluation of Health and Nutritional Properties of Probiotics in Food Including Powder Milk with Live Lactic Acid Bacteria, Cordoba, Argentina, 1-4 October 2001, and Report of a Joint FAO/WHO Working Group on Drafting Guidelines for the Evaluation of Probiotics in Food, London, Ontario, Canada, 30 April-1 May 2002 [FAO Food and Nutrition paper 85], pp. 1-50, Rome, Italy:World Health Organization (WHO), Food and Agricultural Organization (FAO) [of the United Nations], ISBN 9251055130, see [1], accessed 11 June 2015.

Maragkoudakis, PA.; Zoumpopoulou, G.; Miaris, C.; Kalantzopoulos, G. Pot, B. and Tsakalidou E. (2006). Probiotic potential of Lactobacillus strains isolated from dairy products. Int. Dairy J.: 16:189-199.

National committee for clinical laboratory standard (NCCLS). (2002). Performance standard for antimicrobial susceptibility test, Twelfth informational supplement (M100-S12).

Radulovic, Z.; Petrovic, T. and Bulajic, S. (2012). "Antibiotic susceptibility of probiotic bacteria, antibiotic resistant bacteria," A Continuous Challenge in the New Millennium ed. Pana M., editor. (Belgrade: University of Belgrade, Faculty of Agriculture, Republic of Serbia;) 550-576

Rammelsberg M. and Radler, F. (1990). Antibacterial polypeptides of Lactobacillus species. J Appl Bacteriol, 69. 177-184.

Riaz, M.; Amir, M.; Akhtar, S.; Farooq, A.; Ismail, A.; Ismail, T.; Hameed, A. (2015). Bacteriological analysis of street vended raw milk in Multan. Pakistan J. Zool., 47: 568-571.

Rodgers, S. (2008). Novel applications of live bacteria in food services: probiotics and protective cultures. Trends Food Sci. Tech. 19, 188e197.

Schlundt, J. (2012). "Health and Nutritional Properties of Probiotics in Food including Powder Milk with Live Lactic Acid Bacteria" Report of a Joint FAO/WHO Expert Consultation on Evaluation of Health and Nutritional 
Properties of Probiotics in Food Including Powder Milk with Live Lactic Acid Bacteria. FAO / WHO. October 22, 2012.

Singhi, SC. and Baranwal, A. (2008). Probiotic use in the critically ill. Indian J Pediatr. 2008;75(6).

Singhi,SC. and Kumar, S. (2016). "Probiotics in critically ill children.". F1000Res (Review). 5: 407. PMC 4813632.

Thirabunyanon, M. and Boonprasom, P. (2009). Niamsup Probiotic potential of lactic acid bacteria isolated from fermented dairy milks on antiproliferation of colon cancer cells Biotechnol. Lett., 31.pp. 571-576.

Thongaram, T. (2016). In vitro evaluation of selected probiotic properties of lactic acid bacteria isolated from the traditional fermented vegetable, Conference Proceeding. Paper presented at International scientific conference on probiotics and prebiotics.Budapest. In Kysucke Nove Mesto, ISBN - 978-80-89589-14-2.

Tulumoglu, S.; Yuksekdag, ZN.; Beyatli, Y.; Simsek, O.; Cinar, B.; Yaşar, E. (2013). Probiotic properties of lactobacilli species isolated from children's feces. Anaerobe. 24:36-42.

Yavuzdurmaz, H. (2007). Isolation, caracterisation of probiotic properties of lactic acid bacteria from human milk. Master of Science in Food Engineering IZMIR.

Yu, B. and Tsen, HY. (1993). Lactobacillus cells in the rabbit digestive tract and the factors affecting their distribution. J Appl Bacteriol. 75(3):269-75.

Yu, prosekov; Babich, O.O. and Bespomestnykh, K. V. (2013). Identification of industry important lactic acid bacteria in foodstuffs. Issn 2308-4057. Foods and Raw Materials Vol. 1 (No. 2).

Zago, M.; Fornasari, M.E.; Carminati, D.; Burns, P.; Suàrez, V.; Vinderola, G.; Reinheimer, J. and Giraffa, G. (2011). Characterization and probiotic potential of Lactobacillus plantarum strains isolated from cheeses Food Microbiol., 28. pp. 1033-1040.

Zamani, B.; Hamid, R.; GOLKAR, Shima, F.; Modjtaba, E.; Maryam, T.; Parvaneh, J.; Reyhaneh, A.; Mohsen, T.; Mohammad R. M. and Zatollah A. (2016). Clinical and metabolic response to probiotic supplementation in patients with rheumatoid arthritis: a randomized, double-blind, placebo-controlled trial. International Journal of Rheumatic Diseases 2016; 19: 869-879. 


\section{الخــلاصة}

البروبيوتيك هي كائنات حية دقيقة غير الممرضة ذات اثر مفيد، عندما يتم استهلاكها بكميات كافية . وتعتبر منتجات الألبان التقليدية مصادر جيدة للبروبيوتيك. تهدف الدراسة الحالية إلى عزل بكتيريا حمض اللاكتيك من منتجات الألبان (جبنة قريش) في محافظة الثرقية بمصر وتقييم إمكاناتها الحيوية . تم عزل اللاكتوباسيلس عن طريق زراعة العينات على بيئة (MRS). تم فحص العزلات لإمكانية اظهار ها كبروبيوتيك باستخدام الاختبار ات في المختبر، بما في ذلك المقاومة مع الحمض والصفراء، و البقاء على قيد الحياة في ظروف الجهاز الهضدي، والنشاط الانحلالي وكذلك الحساسية للمضادات الحيوية. وبالإضافة إلى ذلك تم تحديد النشاط المضاد للبكتيريا من سلالات معزولة ضد الايشريكيا القولونية H7:H7 م157 و السالمونيلا المعوية . اظهرت لاكتوباسيلس ديلبروكي تحت جنس لاكتس اعلى درجة من المقاومة لدرجات الحموضة المنخفضة، و الصفر اء وظروف الجهاز الهضمي ـ أظهرت هذه السلالة مقاومة ضد المضادات الحيوية , حمض ناليديكسيك، كلوكساسيلين، أزنريونام وكو ليستين , وكذلك فعالية النشاط المضاد للبكتيريا ضد اثنين من مسببات الأمر اض السلبية غرام والتي هي محللة للام. وأخيرا ، تم تعريف سلالة لاكتوباسيلس ديلبروكي تحت جنس لاكتس. باستخدام الطرق البيوكيميائية و الجزيئية.

في الدر اسة الحالية، عزلت بكتريا لاكتوباسيلس ديلبروكي تحت جنس لاكتس من منتجات الألبان (جبنة قريش). حيث أظهرت البكتيريا خصائص بروبيوتيك جيدة. 